\title{
Media Eksakta
}

Journal available at: http://jurnal.fkip.untad.ac.id/index.php/jme

e-ISSN: 2776-799x p-ISSN: 0216-3144

\section{Penentuan Kadar Natrium (Na) dan Kalsium (Ca) Pada Air Laut Desa Posona}

\author{
Determination of Sodium ( $\mathrm{Na}$ ) and Calcium (Ca) Levels in Sea water at Posona Village
}

\author{
Burhan*, Suherman, P. H. Abram \\ Program Studi Pendidikan Kimia FKIP Universitas Tadulako \\ *e-mail: putraburhansya@gmail.com
}

\section{Article Info}

\section{Article History:}

Received: 30 April 2021

Accepted: 20 Mei 2021

Published: 31 Mei 2021

\section{Keywords:}

Sodium $(\mathrm{Na})$

Calcium $(\mathrm{Ca})$

Seawater

Atomic Absorption

Spectrophotometer $(A A S)$

Flame Photometer

\begin{abstract}
It has been done a study on the determination of sodium ( $\mathrm{Na}$ ) and calcium (Ca) levels in seawater at Posona Village. The aims of this study were to determine the levels of sodium ( $\mathrm{Na}$ ) and calcium (Ca) in seawater in Posona village. The tools used were an atomic absorption spectrophotometer (AAS) and a flame photometer. Seawater samples were taken in the morning and afternoon in 3 distance points: 50 meters, 100 meters, and 150 meters from the edge of the land surface of the seashore. The level of sodium ( $\mathrm{Na}$ ) was measured at wavelengths of $589 \mathrm{~nm}$ while calcium (Ca) at a wavelength of $422.7 \mathrm{~nm}$. The results of the study obtained the sodium levels in the morning samples with a distance of $50 \mathrm{~m}, 100 \mathrm{~m}$, and $150 \mathrm{~m}$ amounted of $18.076 \mathrm{mg} / \mathrm{L}, 18.395 \mathrm{mg} / \mathrm{L}$, and $18.715 \mathrm{mg} / \mathrm{L}$. While the afternoon samples for the sodium ( $\mathrm{Na}$ ) levels was $18.475 \mathrm{mg} / \mathrm{L}, 18.742 \mathrm{mg} / \mathrm{L}$, and $18.249 \mathrm{mg} / \mathrm{L}$, respectively. The results of the analysis of calcium levels in the morning samples were $8.431 \mathrm{mg} / \mathrm{L}, 8.8 \mathrm{mg} / \mathrm{L}$, and $7.661 \mathrm{mg} / \mathrm{L}$, whereas in the afternoon for calcium (Ca) levels were $9.415 \mathrm{mg} / \mathrm{L}, 9.231 \mathrm{mg} / \mathrm{L}$, and $7.692 \mathrm{mg} \mathrm{L}$, respectively.
\end{abstract}

\section{PENDAHULUAN}

Indonesia adalah negara kepulauan terbesar di dunia yang terdidri dari 17.504 pulau, panjang garis pantai diseluruh wilayah indonesia menurut data yang dikeluarkan oleh The World Factbook (TWF) [1], dari buku yang diterbitkan oleh CentralIntelligence Agency adalah $54.716 \mathrm{~km}^{2}$. Indonesia menempati urutan kedua negara dengan panjang garis pantai terpanjang setelah kanada diantara 198 negara dan 55 wilayah dunia [1].

Air laut adalah suatu komponen yang berinteraksi dengan lingkungan darat, dimana buangan limbah dari daratan akan bermuara kelaut. Limbah yang mengandung polutan tersebut akan masuk kedalam ekosistem perairan pantai dan laut. Sebagian laut dalam air, sebagian tenggelam ke dasar dan terkosentrasi ke sedimen, dan sebagian masuk kedalam jaringan tubuh organisme laut [2].

Potensi sumber daya laut (hayati dan non hayati) di kawasan kedaulatan NKRI dengan panjang garis pantai $95.181 \mathrm{Km}$ dan luas laut $5,800.000 \mathrm{Km}^{2}$ [3]. Sumberdaya tersebut dibagi dalam sumberdaya terbarukan (renewable resources), seperti perikanan dan hutan mangrove, dan sumberdaya tidak terbarukan (non renewable resources), seperti batu bara, minyak dan gas bumi, dan bahan tambang. Air laut mengandung $86 \%$ natrium klorida $(\mathrm{NaCl})$. Natrium mempunyai peran penting dalam keseimbangan cairan, kontraksi otot, sistem saraf, dan berperan dalam distribusi cairan tubuh. Konsentrasi ion natrium dalam plasma (ekstraseluler) adalah 130-145 mmol/L [4].

Pengetahuan mengenai batuan (petrologi), diperlukan untuk mendapatkan berbaga jenis mineral logam. Kelompok batuan tersusun dari berbagai jenis mieral dan mineral tersusun dari berbagai jenis unsur kimia [5].

Batuan memberikan pengaruh yang signifikan terhadap sumber daya air, baik dari sisi sumber air, daya air maupun keberadaan air. Pada bagian dasar groundwater ada kontak antara air dan batuan yang memberikan pengaruh kimiawi terhadap air sehingga kandungan kimia air yang mengalir akan mengalami evolusi sesuai dengan lokasi aliran air. Unsurunsur kimia yang larut dalam air tanah berjalan dan berevolusi lewat jalan aliran tanah. Ia menyelidiki bahwa evolusi ini diikuti oleh perubahan regional dari spesies anion yang dominan [6].

Sebagian besar wilayah repoblik Indonesia berupa perairan laut yang letaknya sangat strategi. Perairan laut Indonesia selain dimanfaatkan sebagai sarana perhubungan lokal maupun internasional, juga memiliki sumber daya laut yang sangat kaya dan penting antala lain sumber daya perikanan, terumbu karang, bahan tambang, dan pada daerah pesisir dapat dimanfaatkan sebagai objek wisata yang menarik [7]. 
Perairan laut Indonesia selain dimanfaatkan sebagai sarana perhubungan lokal maupun internasional, juga memiliki sumber daya laut yang sangat kaya, antara lain sumber daya perikanan, terumbu karang, mangrove, bahan tambang, dan daerah pesisir pantai dapat di manfaatkan sebagai wisata yang menarik. Pencemaran laut diartikan sebagai adanya kotoran atau hasil buangan aktivitas mahluk hidup yang masuk ke daerah laut [8].

Posona adalah tempat wisata permandian pantai, lokasi tersebut terdapat penangkaran kerang mutiara oleh PT. Timor Otsuki Mutiara (TOM) dari Nusa Tenggara Timur (NTT). Tempat ini digunakan sebagai tempat pembesaran bibit kerang mutiara yang bibitnya dibawa langsung dari NTT. Setelah beberapa bulan bibit kerang mutiara di bawah lagi ke NTT untuk proses habitat selanjutnya. Lokasi ini dipilih tentu melalui pertimbangan dari berbagai penelitian bahwa kerang mutiara dapat berkembang biak dengan baik jika: Perairan laut yang tenang, dasar perairan sebaiknya dipilih berkarang dan berpasir pecahan karang merupakan alternatif yang sesuai, arus tenang merupakan tempat yang paling baik hal ini bertujuan untuk menghindari teraduknya pasir perairan yang masuk kedalam tiram, salinitas 24 ppt dan 50 ppt tapi jangka waktu pendek yaitu 2-3 hari tapi sebaiknya 32-35 ppt kandisi ini baik untuk kelangsungan kerang mutiara, suhu yang baik untuk hidup kerang mutiara berkisar $25-31^{\circ} \mathrm{C}$, kecerahan, $\mathrm{pH}$ 6,7,8 agar kerang mutiara dapat berkembang dengan baik, dan oksigen. Air laut adalah cairan yang bersifat agak basa $(\mathrm{pH}$ $7,5-8,4$ ) yang merupakan campuran lebih dari 80 unsur, gas dan senyawa organik terlarut. Konsentrasi campuran unsurunsur tersebut beragam dan berbeda tergantung pada faktor tempat (geografis) dan fisik pengukuran salinitas air laut dalam ppt (\%) yang menunjukkan konsentrasi senyawa terlarut. Ion-ion utama penyusun air laut adalah: natrium 55\%, klor $31 \%$, sulfat $8 \%$, magnesium $4 \%$, kalsium $1 \%$ dan kalium $1 \%$. Laut di garis lintang subtropis memiliki salinitas tertinggi sebagai akibat dari suhu yang lebih tinggi, sedangkan laut di kawasan sedang (temperate) memiliki salinitas lebih rendah karena rendahnya evaporasi. Laut terbuka memiliki salinitas tetap dengan kisaran 34-37\%, dengan perbedaan kelarutan akibat curah hujan dan evaporasi. Kawasan tertutup seperti laut Merah dan Teluk Ara, memiliki saliitas 44\% (Sidharta, 2016).

Dilokasi permandian ini ternyata orang dapat mengapung dalam posisi telengkup maupun menengadah. Artinya bahwa kadar garam disekitar lokasi ini lebih tinggi dari lokasi lain. Gejala ini hampir sama seperti yang terjadi di laut mati walaupun tidak $100 \%$ kandungan kadar garamnya sama persis dengan kandungan kadar garam di laut mati. Kadar garam di laut mati $\pm 33.5 \%$ sedangkan kandungan garam air laut pada umumnya hanya berkisar $\pm 3.5 \%$. Garam ini berasal dari bebatuan di darat yang terbasuh dan larut oleh kandungan asam oleh air hujan hingga terbawa kelaut, garam ini umumnya adalah natrium $(\mathrm{Na})$ dan klorida $(\mathrm{Cl})$ yang kemudian terakumulasi dilaut sebagai garam. Penguapan air adalah faktor yang signifikan dalam meningkatkan tingkat natrium selama musim panas. Seperti natrium, kalium juga merupakan elemen alami, tetapi konsentrasinya lebih rendah dari natrium dan kalsium [9].

Dalam proses mineralisasi tulang Ca dan $\mathrm{P}$ memiliki peran yang penting karena sekitar $80-90 \%$ unsur tulang tersusun dari
$\mathrm{Ca}, \mathrm{P}$ dan Mg [10]. Menurut Rocha [11], kalsium dan fosfor berhubungan erat dengan pengembangan kerangka dan pemeliharaan dan mineralisasi tulang.

Garam adalah suatu kumpulan senyawa kimia dengan penyusun terbesar adalah natrium klorida $(\mathrm{NaCl})$ dan pengotor yaitu klasium sulfat $\left(\mathrm{CaSO}_{4}\right)$, magnesium sulfat $\left(\mathrm{MgSO}_{4}\right)$, dan magnesium klorida $\left(\mathrm{MgCl}_{2}\right)$. Garam alami mengandung senyawa magnesium klorida, magnesium sulfat, magnesium bromida, dan senyawa runut lainnya. Air laut mengandung $86 \%$ natrium klorida $(\mathrm{NaCl})$ [12].

Sedangkan ikan-ikan mendapatkan fosfat melalui rantai makanan [13]. Penelitian lain yang dilakukan oleh Adebayo \& Omitoyin [14] pada ikan, Ca kompleks dengan $\mathrm{P}$ dalam hidroksiapatit $\left[\begin{array}{lllll}3 \mathrm{Ca}_{3} & \left(\mathrm{PO}_{4}\right)_{2} & \mathrm{Ca} & (\mathrm{OH})_{2}\end{array}\right]$ berfungsi untuk membentuk kepala, ekor, bahan kristal tulang dan berpartisipasi dalam beberapa proses fisiologi.

Tulisan ini dimaksudkan untuk mendeskripsikan tentang penentuan kadar Natrium (Na) dan Kalsium $\mathrm{Ca}$ ) pada air laut desa Posona.

\section{METODE}

Alat-alat yang digunakan yaitu seperangkat alat SSA (Spektra AA 932) dan flame fotometer, botol berwarna gelap $150 \mathrm{~mL}$, Labu ukur $100 \mathrm{~mL}$, Gelas ukur $50 \mathrm{~mL}$, Gelas kimia, penangas listrik, pipet tetes, $\mathrm{pH}$ meter, botol semprot, corong, pipet ukur, alumunium foil, dan kertas label. Sedangkan untuk bahan yang digunakan yaitu air laut yang akan diteliti, aquades, asam nitrat $\left(\mathrm{HNO}_{3}\right)$ pekat, $\mathrm{Ca}\left(\mathrm{NO}_{3}\right), \mathrm{NaNO}_{3}$, kertas saring dan tissue.

\section{Pegambilan sanpel dan penyiapan cuplikan}

Pengambilan sampel air laut dilakukan pada pagi dan sore hari dengan 3 titik tempat pengambilan sampel yaitu pada jarak $\pm 50 \mathrm{~m}, 100 \mathrm{~m}$, dan $150 \mathrm{~m}$ dari tepi pantai desa posona . sampel air laut diambil dengan menggunakan botol berwarna gelap, yang berukuran $100 \mathrm{~mL}$ kemudian sampel air laut ditetesi sebanyak $1 \mathrm{~mL}$ (20 tetes) dengan larutan asam nitrat $\left(\mathrm{HNO}_{3}\right)$ pekat. selanjutnya sampel dibawa kelaboratorium untuk dianalisis. Larutan $\mathrm{HNO}_{3}$ pekat berfungsi untuk melarutkan logam-logam yang terdapat di dalam sampel, karena $\mathrm{HNO}_{3}$ pekat merupakan pelarut logam yang universal dan dapat menstabilkan logam-logam yang akan dianalisis [15].

\section{Penentuan kadar logam Natrium (Na) dengan alat flame fotometer}

Sampel air laut diambil sebanyak $10 \mathrm{~mL}$ lalu disaring, kemudian dimasukkan ke dalam gelas kimia dan $\mathrm{pH}$ nya diatur sampai 5 lalu dianalisis dengan flame fotometer dengan panjang gelombang $589 \mathrm{~nm}$ untuk logam natrium. Data yang diperoleh dibuat kedalam persamaan kurva kalibrasi sehingga diperoleh nilai konsentrasi.

\section{Penentuan kadar logam Kalsium (Ca) dengan alat spektrofotometer serapan atom}

Sampel air laut diambil sebanyak $10 \mathrm{~mL}$ lalu disaring, kemudian dimasukkan ke dalam gelas kimia dan pHnya diatur sampai 5 lalu dianalisis dengan Spektrofotometer Serapan Atom pada panjang gelombanag 422,7 nm untuk logam 
Kalsium. Data yang diperoleh dibuat kedalam persamaan kurva kalibrasi sehingga diperoleh nilai konsentrasi.

\section{HASIL DAN PEMBAHASAN}

Pengambilan sampel air laut dilakukan pada pagi hari dan sore hari, kemudian sampel air laut tersebut ditetasi $\mathrm{HNO}_{3} 65 \%$ sebanyak $1 \mathrm{~mL}$. tujuan penambahn $\mathrm{HNO}_{3}$ sebagai bahan pengawet sampel.

\section{Natrium (Na)}

Berdasarkan hasil pengamatan dan perhitungan dengan menggunakan persamaan regresi linear yakni:

$$
\mathrm{y}=\mathrm{a}+\mathrm{bx}
$$

maka diperoleh kosentrasi Natrium (Na) pada sampel yang terlihat pada diagram dibawah ini:

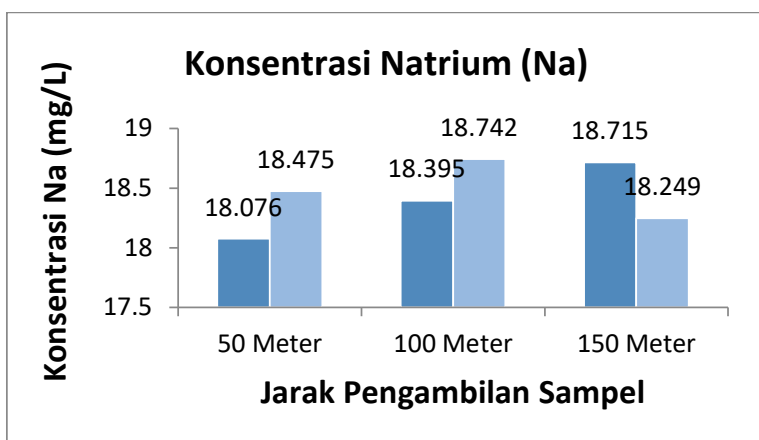

Gambar 1. Grafik kosentrasi natrium (Na) pada ( pagi dan $\square$ sore).

Sampel air laut yang diambil berdasarkan dua ketentuan yakni pagi hari dan sore hari yaitu pada pagi hari jarak 50 meter sebesar $18.078 \mathrm{mg} / \mathrm{L}$, jarak 100 meter sebesar 18.395 $\mathrm{mg} / \mathrm{L}$, dan pada jarak 150 meter sebesar $18.715 \mathrm{mg} / \mathrm{L}$. Sedangkan untuk sampel air laut yang diambil pada waktu sore hari pada jarak 50 meter sebesar $18.475 \mathrm{mg} / \mathrm{L}$, jarak 100 meter sebesar $18.742 \mathrm{mg} / \mathrm{L}$, dan jarak 150 meter sebesar $18.249 \mathrm{mg} / \mathrm{L}$. Dari hasil perhitungan ini menunjukan bahwa kadar logam Natrium yang diambil pada sore hari dengan jarak 50-100 meter cukup tinggi dibandingkan pengambilan sampel pada sore hari. Sedangkan pada jarak 150 meter berbanding terbalik dengan apa yang ada pada jarak sebelumya yaitu berkisar antara $18.715 \mathrm{mg} / \mathrm{L}$ untuk pagi harinya sedangkan $18.249 \mathrm{mg} / \mathrm{L}$ untuk sore harinya.

Kadar natrium dan kalium dari sampel air laut, dihitung berdasarkan persamaan kurva baku (regresi), untuk natrium 100-500 ppm dan kalium 10-50 ppm. Regresi merupakan kurva yang menyatakan hubungan antara dua besaran. Contoh regresi sederhana adalah hubungan antara konsentrasi dengan absorbansi pada spektrofotometri. Hubugan antara kedua besaran dapat dilukiskan $\mathrm{y}=\mathrm{bx}+\mathrm{a}, \mathrm{y}=$ menyatakan absorbansi, $\mathrm{x}=$ konsentrasi, $\mathrm{b}=$ koefisien regresi (juga menyatakan slope $=$ kemiringan $), a=$ tetapan regresi dan juga disebut intersep [16].

Beberapa faktor yang mempengaruhi kadar logam Natrium yaitu tingginya curah hujan pada saat pengambilan sampel yaitu padasaat penagambilan sampel cuaca setelah hujan, dan adanya sungai atau muara besar disekitasan tempat pengambilan sampel.
Natrium mempunyai peran penting dalam keseimbangan cairan, kontraksi otot, sistem saraf, dan berperan dalam distribusi cairan tubuh. Konsentrasi ion natrium dalam plasma (ekstraseluler) adalah 130-145 mmol/L [4].

Natrium Klorida ( $\mathrm{NaCL}$ ) atau yang biasa dikenal dengan sebutan garam dapur sudah sejak lama dikenal masyarakat sebagai pemberi rasa asin dan dapat mencegah kebusukan. [17].

Hasil analisa terhadap garam yang dihasilkan oleh masyarakat di Pulau Madura menunjukkaan, bahwa semakin tinggi konsentrasi Natrium Chlorida $(\mathrm{NaCl})$, maka kandungan magnesium $(\mathrm{Mg})$ di dalam garam akan semakin rendah [18].

Menurut [19]. Natrium adalah kation utama dalam darah dan cairan ekstraselular. Fungsi natrium di dalam tubuh bersama-sama dengan kalium menjaga keseimbangan cairan di dalam tubuh dan sebagai penghantar impuls dalam serabut syaraf. Kebutuhan natrium diperkirakan sebesar $500 \mathrm{mg} / \mathrm{hari}$ [20]. Sumber natrium yang relatif tinggi terdapat pada tanah garaman yaitu tanah yang dekat dengan laut [19].

\section{Kalsium (Ca)}

Berdasarkan hasil pengamatan dan perhitungan dengan menggunakan persamaan regresi linear yakni y $=a+b x$ maka diperoleh koentrasi Kalsium (Ca) pada sampel yang terlihat pada digram dibawah ini:

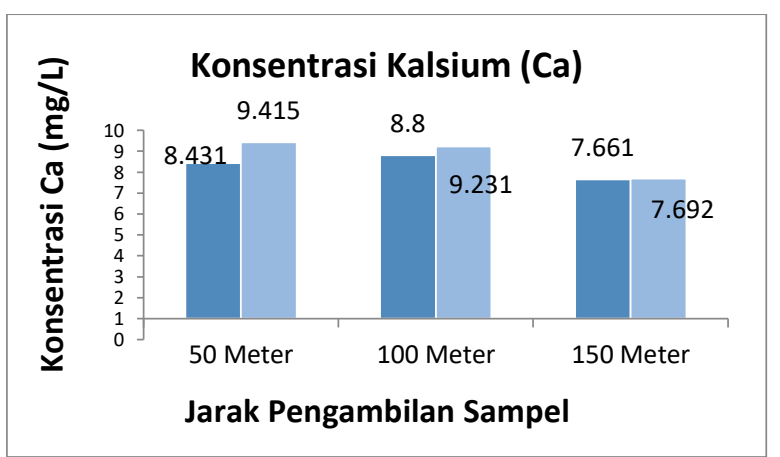

Gambar 2. Grafik kosentrasi kalsium (Ca) pada dan $\square$ sore).

Pada pagi hari jarak 50 meter sebesar $8.431 \mathrm{mg} / \mathrm{L}$, jarak 100 meter sebesar $8.8 \mathrm{mg} / \mathrm{L}$, dan pada jarak 150 meter sebesar $7.661 \mathrm{mg} / \mathrm{L}$. Sedangkan untuk sampel air laut yang diambil pada waktu sore hari pada jarak 50 meter sebesar $9.415 \mathrm{mg} / \mathrm{L}$, jarak 100 meter sebesar $9.231 \mathrm{mg} / \mathrm{L}$, dan jarak 150 meter sebesar $7.692 \mathrm{mg} / \mathrm{L}$. Hasil perhitungan ini menunjukan bahwa kadar logam Kalsium yang diambil pada sore hari dengan jarak 50-100 meter cukup tinggi dibandingkan pengambilan sampel pada sore hari. Sedangkan pada jarak 150 meter berbanding terbalik dengan apa yang ada pada jarak sebelumya yaitu berkisar antara $7.661 \mathrm{mg} / \mathrm{L}$ untuk pagi harinya sedangkan $7.692 \mathrm{mg} / \mathrm{L}$ untuk sore harinya.

Adapun beberapa faktor yang mempengaruhi kadar logam Kalsium tersebut yaitu tingginya curah hujan pada saat pengambilan sampel yaitu padasaat penagambilan sampel cuaca setelah hujan, dan adanya sungai atau muara besar disekitasan tempat pengambilan sampel. Meningkatnya konsentrasi $\mathrm{Ca}$ dalam tanah maka akan menurunkan konsentrasi K. Semakin tinggi kadar kalium yang diperoleh maka akan semakin rendah kadar kalsium yang akan diperoleh 
[21]. Tanaman yang memiliki cukup kalium dapat mempertahankan kandungan air yang terdapat dalam jaringannya, karena mampu menyerap lengas (kelembaban) dari tanah dan mengikat air sehingga tanaman tahan terhadap cekaman kekeringan [22].

Kalsium (Ca) merupakan mineral paling banyak yang terdapat dalam tubuh dan $99 \%$ ditemukan di kerangka manusia. Fungsi dari kalsium adalah untuk membentuk rangka yang kuat, melindungi organ yang penting serta membantu pergerakan dan pertumbuhan [23]. Kalsium merupakan salah satu nutrien esensial yang dibutuhkan untuk berbagai fungsi tubuh [24]. Mengkonsumsi makanan bersumber kalsium dianjurkan bagi lanjut usia terutama pada perempuan pasca menopause mengingat risiko mengalami osteoporosis lebih besar dengan kondisi menopause dan asupan kalsium yang tidak mencukupi kebutuhan [25].

Kalsium merupakan unsur hara semi makro yang dibutuhkan tanaman. Kadar kalsium yang tinggi dalam tanah umumnya berpengaruh terhadap kemasaman tanah. Kalsium menyebabkan kemasaman tanah menjadi rendah atau $\mathrm{pH}$ tanah tinggi. Kalsium berperan sebagai nutrisi tanaman yang diperlukan untuk pertumbuhan dan perkembangan khususnya akar dan tunas [26]. Kalsium didalam tanaman sangat penting untuk menetralisasi senyawa asam. Senyawa asam ini bila konsentrasinya terlalu tinggi, mempunyai pengaruh negatif terhadap tumbuhan [27].

Selain kandungan serat dan manfaatnya, labu siam kaya mineral yang bermanfaat bagi tubuh kita apabila dikonsumsi dalam jumlah yang cukup. Mineral adalah salah satu gizi yang diperlukan oleh tubuh. Seperti kalium dan kalsium yang merupakan makromineral. Mengkonsumsi makanan dalam jumlah yang cukup sangatlah memberikan manfaat yang besar bagi tubuh kita. Namun mengkonsumsi makanan dalam jumlah yang kurang atau berlebih malah sangat beresiko pada tubuh [28].

\section{KESIMPULAN}

Berdasarkan penelitian dan analisis yang telah dilakukan dapat disimpulkan bahwa kosentrasi logam Natrium (Na) pada air laut desa Posona yaitu untuk pagi hari $18.395 \mathrm{mg} / \mathrm{L}$, sedangkan untuk sore hari $18.488 \mathrm{mg} / \mathrm{L}$ dari nilai rata-rata. konsentrasi tersebut lebih rendah jika dibandingkan dengan kadar Natrium yang ada pada umumnya berkisar antara $\mathrm{NaCl}$ yaitu 3.5 mg/L. Sedangkan untuk kadar logam Kalsium (Ca) pada air laut desa Posona yaitu untuk pagi hari $8.297 \mathrm{mg} / \mathrm{L}$, sedangkan untuk sore hari $8.779 \mathrm{mg} / \mathrm{L}$ dari nilai rata-rata. konsentrasi tersebut lebih tinggi jika dibandingkan dengan jumlah kalsium $(\mathrm{Ca})$ yang ada pada laut umumnya antara berikisar $1 \mathrm{mg} / \mathrm{L}$.

\section{UCAPAN TERIMA KASIH}

Ucapan terima kasih penulis berikan kepada kedua orang tua, saudara-saudara saya dosen-dosen prodi pendidikan kimia, kepala laboran Laboratorium Fakultas Pertanian Ilmu Tanah, kepala laboran Laboratorium FKIP pendidikan Kimia, kepala laboran Laboratorium Kesehatan Daerah Provinsi Sulawesi Tengah Kota Palu dan semua pihak yang banyak membantu penulis dalam menyelesaikan penelitian ini.

\section{REFFERENSI}

[1] The World Factbook, "Statistik sumber daya laut dan pesisir,” BPS-Statistics Indonesia, 2016.

[2] Ika, "Analisis logam timbal $(\mathrm{Pb})$ dan besi $(\mathrm{Fe})$ dalam air laut di wilayah pesisir pelabuhan ferry Taipa Kecamatan Palu Utara," Jurnal Akademika Kimia, 1(4), 2012, pp. 181-186.

[3] R. B. Sidharta, "Bioteknologi kelautan," Yogyakarta: Cahaya Atma Pustaka, 2016, 3-43, 65-6

[4] K. V. Shah, dkk., "Determination of sodium, potassium, calcium and lithium in a wheat grass by flame photometry," ISSN: 0976-7908, 2011.

[5] N. Djauhari, "Geologi lingkungan," Jakarta: UIEU University Press, 2006.

[6] J. R. Kodoatie, \& R. Sjarief, "Tata ruang air," Yogyakarta: ANDI, 2010.

[7] A. Fiskanita, "Analisis logam timbal $(\mathrm{Pb})$ dan besi $(\mathrm{Fe})$ dalam air laut di pelabuhan Desa Paranggi Kecamatan Ampibabo," Jurnal Akademika Kimia, 4(4), 2015, pp. 175-180.

[8] Rengky. (2011). "Kandungan logam berat pada air laut permukaan dan sedimen serta pencemaran limbah padat" [Online]. Tersedia: http://rengkiik08blogspot. com /2011/01/kandungan-logam-berat-pada-air-laut. Html.

[9] R. G. Wetzel, "Limnology-lake and river ecosystems.3rdedition," Academic Press, 2000.

[10]Zainuddin, "Pengaruh kalsium dan fosfor terhadap pertumbuhan, efisiensi pakan, kandungan mineral dan komposisi tubuh juvenil ikan kerapu macan (epinephelus fuscoguttatus)," Jurnal Ilmu dan Teknologi Kelautan Tropis, 2(2), 2010, pp. 1-9.

[11]C. B. Rocha, M. K. Portelinha, J. M. Fernandes, A. C. P. Britto, S. R. N. Piedras, \& J. L. O. F. Pouey, "Dietary phosphorus requirement of pejerrey fingerlings (odontesthes bonariensis)," Revista Brasileira de Zootecnia, 43(2), 2014, pp. 55-59.

[12] Y. M. Paweka, "Analisis natrium dalam air laut di sekitar pesisir pantai papua dengan metode spektroskopi serapan atom," Jurnal Pemerintah Daerah Tingkat I Propinsi Papua 2(7), 2017.

[13] C. X. Ye, Y. J. Liu, L. X. Tian, K. S. Mai, Z. Y. Du, H. J. Yang, \& J. Niu, "Effect of dietary calcium and phosphorus on growth, feed efficiency, mineral content and body composition of juvenil grouper, epinephelus coioides," International Journal of Fisheries and Aquaculture, 2 (5), 2006, pp. 63-71. 
[14]I. A. Adebayo, \& B. O. Omitoyin, "Essentiality of calcium supplement in the diets of heterobranchus bidorsalis fingerlings," International Journal of Fisheries and Aquaculture, 5(5), 2013, pp. 98-103.

[15] S. N. Hidayati, "Kadar kalsium (Ca) dan kalium (K) pada sayur kangkung (Ipomea reptans) yang tumbuh di Kota Palu," Skripsi. Palu: Universitas Tadulako, 2011.

[16]G. I. Gandjar, A. Rohman, "Kimia farmasi analisis," Yogyakarta: Pustaka Pelajar, 2007.

[17]L. Yusmita, "Identifikasi konsentrasi natrium klorida $(\mathrm{NaCl})$ pada jahe dan lengkuas giling dibeberapa pasar tradisional di kota Padang," Jurnal Teknologi Pertanian Andalas, 2(21), 2017, pp. 122-126

[18] M. Zainuri, "Hubungan kandungan natrium klorida $(\mathrm{NaCl})$ dan magnesium $(\mathrm{Mg})$ dari garam rakyat di pulau Madura," Prosiding Seminar Nasional Kelautan, 2016, pp. 167-172.

[19] S. S. Sitanggang, "Penetapan kadar kalsium, kalium dan natrium Nanas (ananas comocus (l) merr) secara spektrofotometer serapan atom," Sumatra Utara: University of Sumatera Utara Institutional Repository, 2013.

[20] S. Almatsier, "Prinsip dasar ilmu gizi," Jakarta: PT. Gramedia Pustaka, 2004.

[21]D. Rahmelia, A. W. M. Diah, \& I. Said, “Analisis kadar kalium (K) dan kalsium (Ca) dalam kulit dan daging buah terung kopek ungu (solanum melongena) asal desa nupa bomba kecamatan tanantovea kabupaten donggala," Jurnal Akademika Kimia, 4(3), 2015, pp. 143-148.

[22] Subandi, "Peran dan pengelolaan hara kalium untuk produksi pangan di Indonesia," Jurnal Pengembangan Inovasi Pertanian, 6(1), 2013, pp. 1-10.

[23] G. D. D. Bangun, L. D Mahfudz, \& D. Sunarti, "Pengaruh penggunaan tepung rumput laut (Gracilaria verrucosa) dalam ransum ayam broiler terhadap berat dan ukuran tulang tibia dan tarsometatarsus," Animal Agricultural Journal, 2(1), 2013, pp. 489-496.

[24]P. Gobinathan, P. V. Murali, \& R. Panneerselvam, "Interactive effects of calcium chloride on salinityinduced proline metabolism in pennisetum typoidies," Advances in Biological Research, 3(5-6), 2009, pp. 168173.

[25] Y. E. Soke, M. Judha, \& T. Amestiasih, "Hubungan pengetahuan lansia tentang osteoporosis dengan perilaku mengkonsumsi makanan berkalsium di panti wredha $\mathrm{x}$ Yogyakarta," Jurnal aKeperawatan Respati, 3(1), 2016, pp. 66-71.
[26] N. Tuteja, \& S. Mahajan, "Calcium signaling network in plants," Journal of Plant Signaling \& Behavior, 2(2), 2007, pp. 79-85.

[27] Suprihatin, "Proses pembuatan pupuk cair dari batang pohon pisang," Jurnal Teknik Kimia, 5(2), 2011, pp. 429433.

[28] N. L. C. Fitriani, "Penentuan kadar kalium (K) dan kalsium (Ca) dalam labu siam (sechium edule) serta pengaruh tempat tumbuhnya," Jurnal Akademika Kimia, 1(4), 2012, pp. 174-180. 